ENGINEERING CHANGE NOTICE

Page 1 of 2

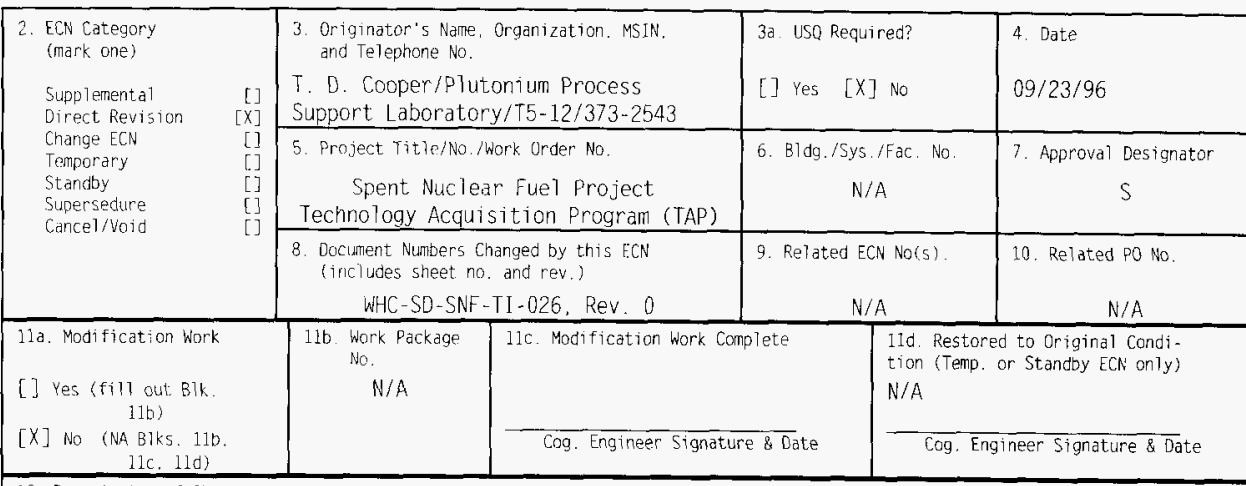

12. Description of Change

Changes in text and equations to clarify document.

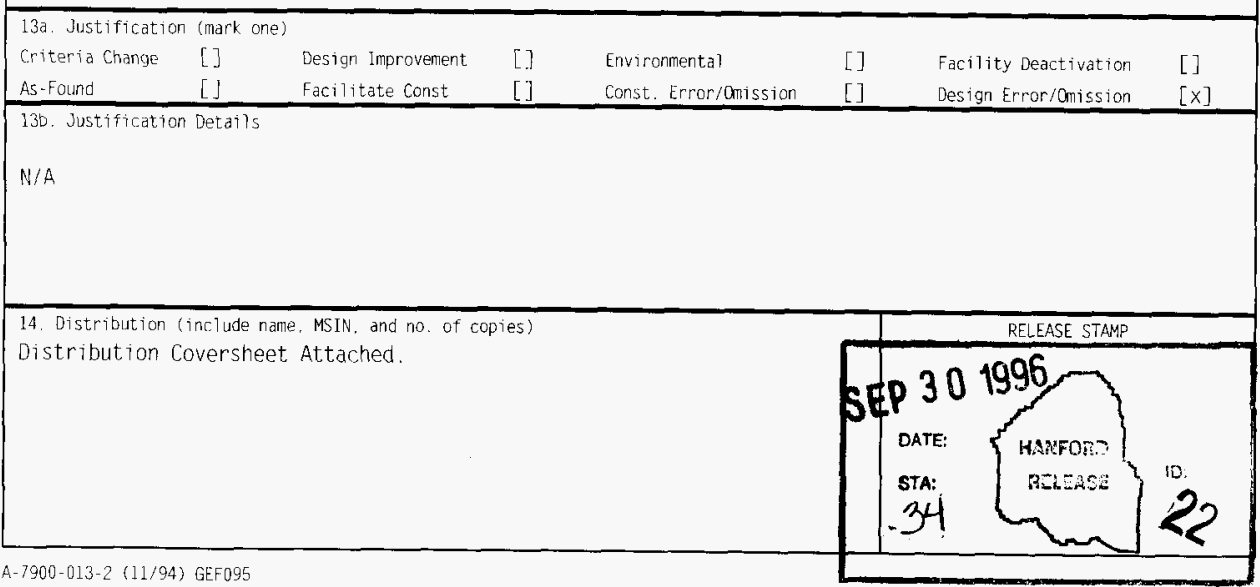




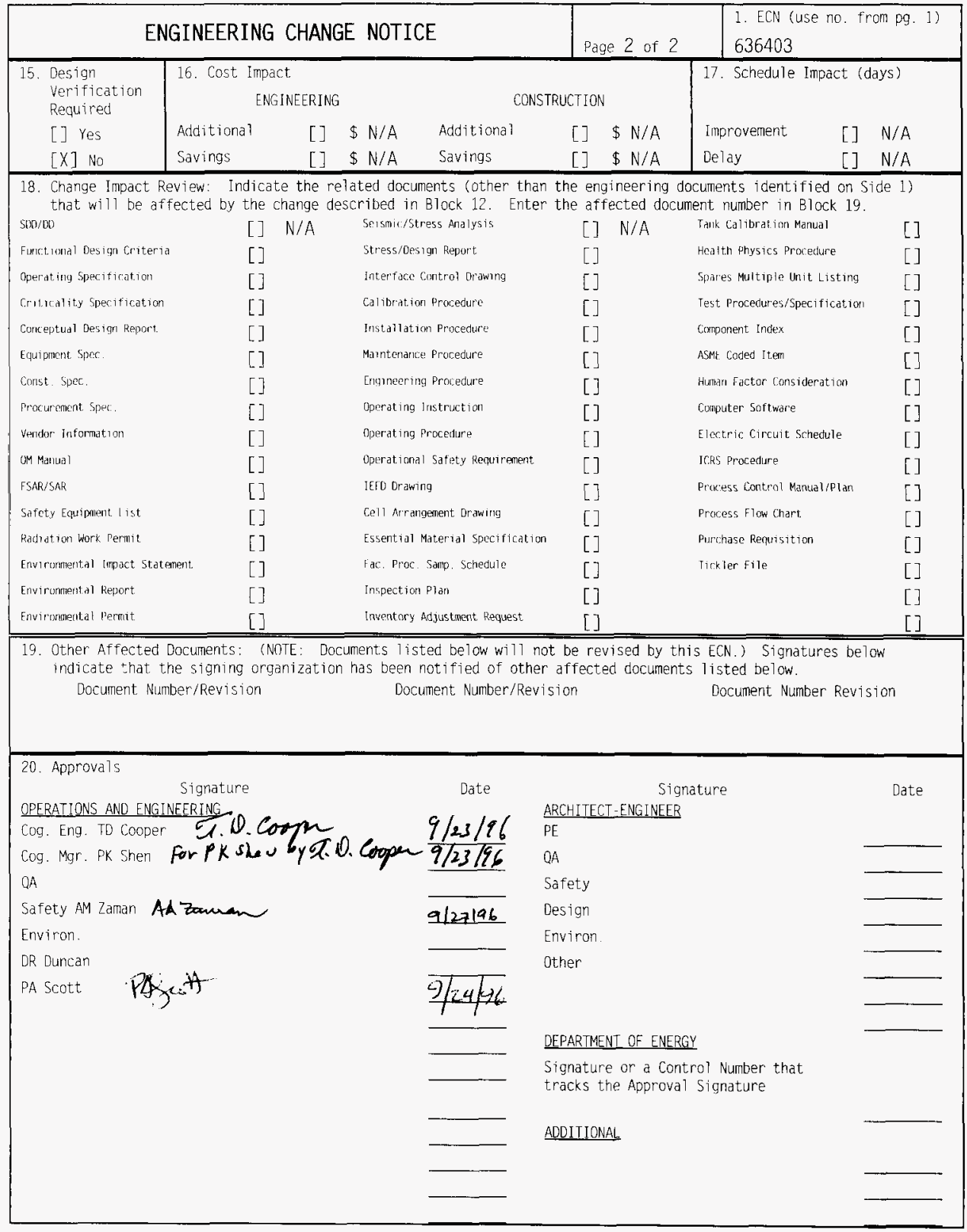




\section{Spent Nuclear Fuel Project Surface Area Estimates For N-Reactor Fuel in the $\mathrm{K}$ East Basin}

Thurman D. Cooper, A. Burt Johnson(PNNL)

Westinghouse Hanford Company, Richland, WA 99352

U.S. Department of Energy Contract DE-AC06-87RL10930

$\begin{array}{ll}\text { EDT/ECN: } 636403 & \text { UC: } 510 \\ \text { Org Code: } 15500 & \text { Charge Code: LB040 } \\ \text { B\&R Code: } \text { EW3135040 } & \text { Total Pages: } 28\end{array}$

Key Words: Surface, Area, N-Reactor, Fuel

Abstract: Spent N-reactor fuel will be moved from wet to dry storage at Hanford Washington. The majority of this fuel exists as intact fuel assemblies, however, small amounts of scrap will be included. Varying amounts of uranium metal are exposed in these fuel assemblies, depending upon the amount of mechanical damage sustained by the zircaloy cladding. The total exposed uranium surface area in each storage pool is estimated through the release of radioisotopes to the storage pools. The exposed uranium surface area of individual fuel assemblies in the K-East basin were estimated through the results of a camera survey. The exposed uranium surface area of scrap is estimated from the known particle side range and an estimated log normal particle size distribution.

This document uses the radioisotope release calculations, the estimated scrap surface area, and the camera survey results to estimate the "worst case" amount of surface area that could exist in a given "MCO" container containing 4 levels of fuel assemblies and one scrap basket. The total exposed uranium metal surface area for this "worst case" was $120,000 \mathrm{~cm}^{2}$

TRADEMARK DISCLAIMER. Reference herein to any specific commercial product, process, or service by trade name, trademark, manufacturer, or otherwise, does not necessarily constitute or imply its endorsement, recommendation, or favoring by the United States Government or any agency thereof or its contractors or subcontractors.

Printed in the United States of America. To obtain copies of this document, contact: WHC/BCS Document Control Services, P.O. Box 1970, Mailstop H6-08, Richland WA 99352, Phone (509) 372-2420; Fax (509) 376-4989.
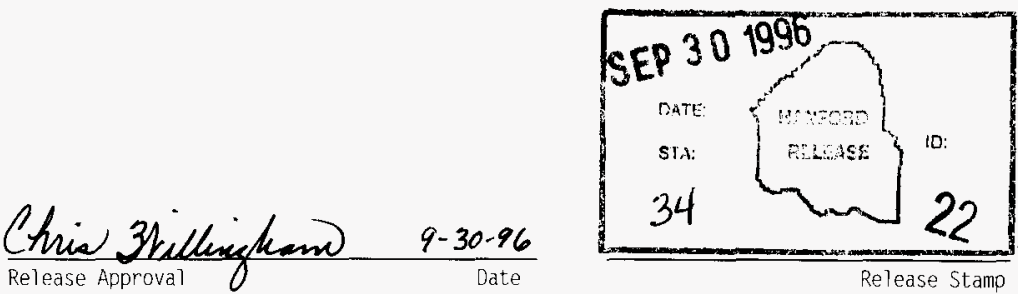

\section{Approved for Public Release}




\section{RECORD OF REVISION}

(1) Document Number

WHC-SD-SNF-TI -026

(2) Title

Spent Nuclear Fuel Project Surface Area Estimates for $N$-Reactor Fuel in the K East Basin

CHANGE CONTROL RECORD

(3)

Revision

1

RS

0
(4) Description of Change - Replace. Add, and Delete pages

(7) Changes in text and equations to clarify document. ECN -636403 EDT- 616630 $8-1-96$
Authorized for Release \begin{tabular}{c|l}
$\begin{array}{l}\text { (5) Cog. } \\
\text { Engr. }\end{array}$ & (6) Cog. Mgr. Date
\end{tabular}

Jivion 
Prepared for the U. S. Department of Energy

Office of Environmental Restoration and Waste Management

Westinghouse Hanford Company

P.O. Box 1970

Richland, WA 99352 
WHC-SD-SNF-TI-026

Revision 1

This page intentionally left blank. 


\section{CONTENTS}

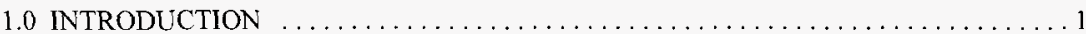

2.0 SURFACE AREA FROM UNDERWATER CAMERA INSPECTIONS . . . . . . 3

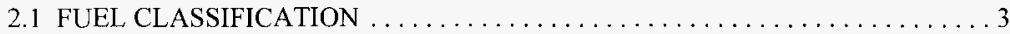

2.2 BASIS FOR URANIUM ACTIVE AREA ESTIMATES FROM VISUAL

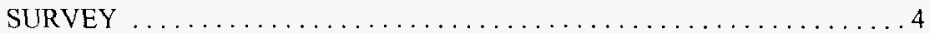

3.0 RADIOMETRIC ESTIMATE OF REACTIVE URANIUM SURFACE AREA

IN THE K-EAST BASIN $\ldots \ldots \ldots \ldots \ldots \ldots \ldots \ldots \ldots \ldots \ldots \ldots \ldots$

4.0 ASSIGNMENT OF REACTIVE URANIUM AREA TO MULTI-CANISTER-

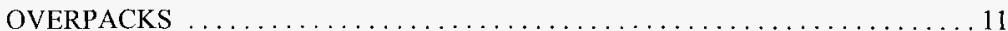

4.1 WORST CASE ASSUMPTION OF THE CORRODING AREA OF

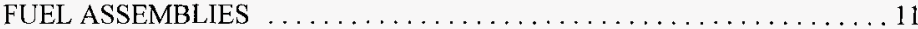

4.2 INVENTORIES OF N-REACTOR FUEL SCRAP (RUBBLE) $\ldots \ldots \ldots \ldots \ldots \ldots$

4.2.1 Current and Projected Fuel Scrap Inventories in the K-East Basin . . . . . 12

4.2.2 Current and Anticipated Fuel Scrap Inventories in K-West . . . . . . . 12

4.2.3 Calculation of Scrap Surface Area Based Upon One Inch Pieces . . . . . . 15

4.2.4 Calculation of Scrap Surface Area Based upon Log Normal

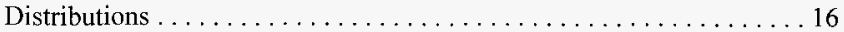

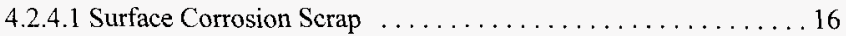

4.2.4.2 Intergranular Corrosion Scrap . . . . . . . . . . . . . 16

4.2.4.3 Mechanical Shock Scrap . . . . . . . . . . . . . . . 17

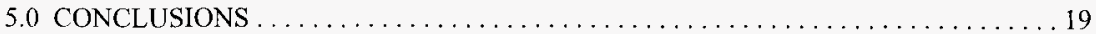

5.1 CORRODING AREA IN K-EAST POOL $\ldots \ldots \ldots \ldots \ldots \ldots \ldots \ldots \ldots \ldots \ldots \ldots$

5.2 CORRODING AREA ESTIMATES FOR AN MCO $\ldots \ldots \ldots \ldots \ldots \ldots \ldots \ldots . \ldots$

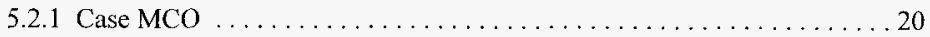

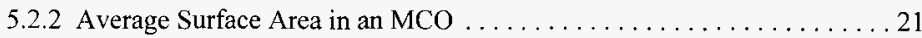

5.2 .3 True Surface Areas . . . . . . . . . . . . . . . . . . . . . . 21

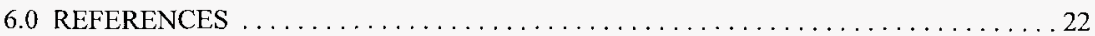


WHC-SD-SNF-TI-026

Revision 1

\section{LIST OF TABLES}

1. Estimated Corroding Surface Areas for Damaged Fuel Elements in K-East Basin . . . . . . 5

2. Fuel Scrap (Rubble) Inventory in K-East Basin $\ldots \ldots \ldots \ldots \ldots \ldots \ldots \ldots \ldots \ldots \ldots$

3. Fuel Scrap (Rubble) Inventory in $\mathrm{K}$-West Basin $\ldots \ldots \ldots \ldots \ldots \ldots \ldots \ldots \ldots \ldots$

\section{LIST OF FIGURES}

1. Assumed Particle Size Distribution for Mechanical Shock Scrap $\ldots \ldots \ldots \ldots \ldots \ldots \ldots$ 
WHC-SD-SNF-TL-026

Revision 1

\section{SPENT NUCLEAR FUEL PROJECT \\ SURFACE AREA ESTIMATES FOR \\ N-REACTOR FUEL IN THE K-EAST BASIN}

\subsection{INTRODUCTION}

The Spent Nuclear Fuel Project at Hanford is tasked with removing spent N-Reactor fuel from the K Basins, placing the fuel in Multi-Container Overpacks (MCOs), drying the fuel, and transporting the fuel to the Canister Storage Building (CSB). At each process step, and during storage, it is important to understand the pyrophoricity hazard, the heat flow from the MCOs, the equilibrium temperature, and the gas generation rates. The corrosion rate of uranium metal with water and oxygen is the critical parameter that determines each of the above items.

Chemical corrosion of uranium metal is a gas-solid or liquid-solid reaction. Since the reaction is occurring at the solid surface and not within the solid volume, the reaction rate is necessarily proportional to the true surface area. The true surface area is differentiated from the geometric surface area by the fact that the surface may contain asperities, roughness, pits, porosity, and cracks. The significance of these factors to N-Reactor fuel surface area has been assessed. A geometric surface area for K-East fuel and a roughness factor to convert the area to true surface area have been estimated (Johnson and Pitner 1996). Methods to measure true surface areas of metals were addressed. The Brunauer-Emmet-Teller (BET) method requires cryogenic conditions and is therefore not practical.

A practical method of estimating surface area is by measuring the reaction products from a surface area-dependent chemical reaction of known rate. During corrosion of the N-Reactor fuel in the K-East pool, radioactive soluble cesium is released. By knowing the ratio of cesium to uranium in the fuel, and by measuring the cesium release rate, the uranium corrosion rate can be estimated if the corrosion rate constant for the specific metal and corrosion conditions is known.

Applying the cesium method is based on the indication by S. R. Tyfield that essentially $100 \%$ of the ${ }^{137} \mathrm{Cs}$ was released from corroding irradiated uranium metal in his investigations (Tyfield 1988). If measurements of the isotope in the $\mathrm{K}$ Basin uranium corrosion products indicate a different value for cesium release, then a correction factor would need to be applied. Neutronics assessments indicate that there is a flux enhancement near the surface of uranium metal that would be expected to result in a somewhat higher near-surface cesium concentration. However, because corrosion of the N-Reactor fuel has been ongoing for 9 to 24 years, cesium enrichment at the surface may already have been predominantly dissipated on much of the corroding surface.

Another key factor necessary to calculate true surface area from ${ }^{137} \mathrm{Cs}$ is the corrosion rate constant, in units of $\mathrm{gU} / \mathrm{cm}^{2} \mathrm{~d}$. The anoxic rate constant is higher by a factor of 20 than the oxic 
rate constant. Since the pool water is oxygenated, oxygenated rate constants were assumed in this report, but it is recognized that diffusion limitation in deep cracks and in beds of sludge may allow a certain percentage of the total corrosion to occur anoxically. Since this percentage is not known, only oxic corrosion rates were used in this report. Ideally the value would be obtained from direct measurement on specimens of corroding uranium from $\mathrm{N}$-Reactor fuel under $\mathrm{K}$ Basin conditions. The only alternative is to obtain from the literature a values that are regarded as relevant to N-Reactor fuel corrosion.

The surface area of the fuel corroding in the K-East Basin was estimated from a visual survey conducted with underwater video (Johnson and Pitner 1996). That assessment also addressed what is known about the key parameters that comprise the true surface area of the corroding N-Reactor fuel. This report addresses an updated estimate of the true surface area of the K-East fuel inventory from ${ }^{137} \mathrm{Cs}$ release rates and also includes estimates of surface area of the various fuel rubble inventories.

Estimates of the entire uranium corrosion occurring in the $\mathrm{K}$-East Basin are obtained from Cs- 137 release rate measurements. From the corrosion rate, one may estimate the corroding area. This corroding area is the currently corroding area, but may not be the true area since certain areas contained within cracks may be temporarily walled off by oxide scale and may not become active until that scale is disrupted through handling or cleaning.

The corroding area of the intact fuel assemblies were estimated from a camera survey of the exposed upper ends of the assemblies. The area of the scrap is estimated from mass of the scrap, and some process knowledge on the relative size of the scrap, but these estimates are not precise because the particle size distribution is not known. This report gives a corroding uranium surface area estimate for the $\mathrm{K}$-East pool, and for a worst case and average $\mathrm{MCO}$, as well as the uncertainty in that area and the range of areas considered. 


\subsection{SURFACE AREA FROM UNDERWATER CAMERA INSPECTIONS}

During the last fuel segregation campaign, the fuel was sorted before shipping to the PUREX reprocessing facility. Two sorting criteria were employed; the first was to ship weapons grade fuel, and the second was to ship relatively intact and non-corroded fuel. As a result, the fuel remaining in the K-East and K-West pools has a larger concentration of corroded and commercial grade fuel compared to its original inventory.

When discharged from the N-Reactor, the fuel was assigned an identification or key number based on discharge date. This key number allows analysts to describe the fuel in terms of its irradiation history and decay time. The fuel was managed in the pools to retain the key number history. During the sorting process, broken fuel assemblies or fragments smaller than sixinches long from a given key were placed in scrap canisters. It is believed that each key will contain at least one canister of scrap, and some keys will contain multiple scrap canisters.

A recent underwater video inspection of the $\mathrm{N}$-Reactor fuel provides the basis for visually estimating the exposed reactive uranium area in the K-East pool (Pitner 1995). Pitner estimates that $42 \%$ of the outer elements and $27 \%$ of the inner elements are corroded to the point that cladding breaches are detectable. This estimate assumes that equal damage is likely to have occurred on both ends of the fuel assemblies and that no effort was made to orient the damaged ends preferentially during the last fuel sorting campaign. The single exception involves the most severely corroded fuel designated split cladding. Operators recall that when these elements were returned to the storage canisters, failed ends of the elements were oriented to the tops of the canisters.

\subsection{FUEL CLASSIFICATION}

Pitner classifies the corroded fuel as follows:

- Incipient: Areas where corrosion is barely evident.

- Rupture: Involving a clear break in the cladding, often with corrosion products extending from the cladding breach, but comprising areas that are less than the full cross section of an element.

- Loose End Cap: Involving a circumferential breach such that the end cap is loosely attached or is detached, generally appearing to comprise corrosion on the full cross section of an element. 
- Split Cladding: Extensive corrosion that has caused splits in the Zircaloy cladding; the full extent of the exposed uranium areas is not observable, but seems to include exposed metal areas that are potentially much larger than a cross section.

\subsection{BASIS FOR URANIUM ACTIVE AREA ESTIMATES FROM VISUAL SURVEY}

The following provides a description of a model used for calculating the surface area from the visual survey (Johnson and Pitner 1996).

A unit area is defined as equal to the geometric cross sectional area of an element; these area units are defined for the outer and inner elements of each assembly as follows:

- $\mathrm{A}_{\mathrm{uv}}=$ area unit of an outer element $=14 \mathrm{~cm}^{2}$

- $\mathrm{A}_{\mathrm{ui}}=$ area unit of an inner element $=7.2 \mathrm{~cm}^{2}$

The distribution of area units among the categories is as follows:

Incipient: The corroding areas are generally barely discernible; the estimated fraction of the cross section that is corroding is $1 \%(0.01)$.

Rupture: The corroding areas are generally much smaller than a full geometric cross sectional area; the average area is estimated to be $25 \%(0.25)$ of the area unit, $A_{u}$.

Loose End Cap: Once the corrosion area has matured, it appears to involve the full cross section; the corroding area is assumed to be equal to the cross sectional area, i.e., to equal one area unit.

Split Cladding: It is assumed that three inches of the metal length are exposed by cladding splits. The corresponding areas for split cladding are:

- outer elements: $17^{*} \Lambda_{\text {чо }}$

- inner elements: $14^{*} A_{\text {ui }}$

The numbers of failed elements and the areas associated are contained in Table 1. The total geometric area is then estimated as:

- outer elements: $=30,000 \mathrm{~A}_{\mathrm{uo}} * 14 \mathrm{~cm}^{2} / \mathrm{A}_{\mathrm{uc}}=4.2 * 10^{5} \mathrm{~cm}^{2}$

- inner elements $=5000 \mathrm{~A}_{\mathrm{ui}} * 7.2 \mathrm{~cm}^{2} / \mathrm{A}_{\mathrm{ui}}=0.4 * 10^{5} \mathrm{~cm}^{2}$

The total visible corrosion is estimated as the sum of the corrosion of the inner and outer elements $=4.7 * 10^{5} \mathrm{~cm}^{2}$, rounded to $5 \times 10^{5} \mathrm{~cm}^{2}$. 

to be $25 \%$.

The uncertainty in visually determining the corrosion area on fuel assemblies is estimated

Table 1. Estimated Corroding Surface Areas for Damaged Fuel Elements in K-East Basin (Johnson and Pitner 1996).

\begin{tabular}{|c|c|c|c|c|c|c|}
\hline \multirow[b]{2}{*}{ Failure Type } & \multicolumn{3}{|c|}{ Outers } & \multicolumn{3}{|c|}{ Inners } \\
\hline & Number & $\begin{array}{c}\text { Area } \\
\text { Factor }\end{array}$ & $\begin{array}{c}\text { Total Area } \\
\text { Units }\end{array}$ & Number & Area Factor & $\begin{array}{c}\text { Total Area } \\
\text { Units }\end{array}$ \\
\hline Incipient & 4,925 & $0.01 \mathrm{~A}_{\mathrm{uo}}$ & $50 \mathrm{~A}_{\mathrm{uo}}$ & 4,830 & $0.01 \mathrm{~A}_{\mathrm{ui}}$ & $50 A_{\mathrm{ui}}$ \\
\hline Rupture & 15,900 & $0.25 \mathrm{~A}_{\mathrm{uo}}$ & $4,000 \mathrm{~A}_{\text {นо }}$ & 9,325 & $0.25 \mathrm{~A}_{\mathrm{us}}$ & $2,330 \mathrm{~A}_{\mathrm{ui}}$ \\
\hline Loose End Cap & 3,180 & $1 A_{\text {ио }}$ & $3,200 \mathrm{~A}_{\mathrm{uo}}$ & 340 & $1 \mathrm{~A}_{\mathrm{ui}}$ & $340 \mathrm{~A}_{\mathrm{ui}}$ \\
\hline Split Cladding & 1,330 & $17 \mathrm{~A}_{\text {uo }}$ & $22,600 \mathrm{~A}_{\mathrm{ud}}$ & 165 & $14 \mathrm{~A}_{\mathrm{ui}}$ & $2,280 \mathrm{~A}_{\mathrm{ui}}$ \\
\hline Totals & & & $30,000 A_{\mathrm{uo}}$ & & & $5,000 \mathrm{~A}_{\mathrm{ui}}$ \\
\hline
\end{tabular}


WHC-SD-SNF-TI-026

Revision 1

This page intentionally left blank. 


\subsection{RADIOMETRIC ESTIMATE OF REACTIVE URANIUM SURFACE AREA IN THE K-EAST BASIN}

Uranium corrosion rates in the K-East pool have varied historically because of changes in the pool water chemistry. For the surface area estimate, it is necessary to ignore spikes in the corrosion rate and to concentrate on the quiescent period obtained recently with high purity water and stable pool chemistry (Johnson and Burke 1995, Fig. 6-2). Under these conditions, it has been estimated that the corrosion rate is 200 grams of uranium per day. This correlates to 27 grams of oxygen being fixed per day as $\mathrm{UO}_{2}$.

The uranium corrosion rate can be expressed mathematically as:

$$
\text { (wt gain } / \mathrm{hr} \text { ) }=\mathrm{K}^{*} \mathrm{~A}_{\text {effective }}
$$

where:

$$
\begin{aligned}
& \text { wt gain = the grams of oxygen fixed as } \mathrm{UO}_{2} \\
& \mathrm{~K}=\text { the linear rate constant in grams (wt gain) } / \mathrm{cm}^{2} / \mathrm{hr} \\
& \mathrm{A}_{\text {effective }}=\text { the effective corroding uranium surface area in the K-East pool. }
\end{aligned}
$$

If both the weight gain per hour and the linear rate constant are known, calculation of the effective surface area can be estimated using Equation 1.

Various linear rate constants are published and have been reported (Cooper 1996). The rate equation for oxygen-free water vapor is a key rate that allows the calculation of liquid water rates as shown below. Units of $\mathrm{K}$ are $\mathrm{mg} \mathrm{O}_{2} / \mathrm{cm}^{2} / \mathrm{hr}$ :

- Oxygen-Free Water Vapor

$$
\begin{aligned}
& \left(\mathrm{T}<373^{\circ} \mathrm{K}\right)(100 \% \mathrm{RH}) \quad \text { (Ritchie 1981) } \\
& \log \mathrm{K}=7.634-3016 / \mathrm{T}
\end{aligned}
$$

\section{- Oxygen Free Liquid Water}

Published rate constants agree closely with rates published for oxygen-free saturated water vapor (Baker 1966). Also, Tyfield's activation energy for oxygen free liquid water is similar to the activation energy published for oxygen free saturated water vapor. 


\section{- Oxygenated Liquid Water}

According to G. E. Zima, uranium corrosion rates in oxygenated water are $1 / 20$ the rates in hydrogen-saturated liquid water (Zima 1960).

Earlier investigators lacked the information on reaction rates of liquid-oxygenated water and used Ritchie's correlations for reactions in the vapor state, which are given below as Equations 3 and 4 . They also used 500 grams of uranium per day as the total corrosion rate on the $\mathrm{K}$-East fuel inventory. This number was based on data accumulated over long periods, and it included data when water chemistry upsets caused spikes in the corrosion rate. Units for the Ritchie equations below are $\mathrm{mg} \mathrm{U} / \mathrm{cm}^{2} / \mathrm{hr}$.

For the oxygenated case at $10^{\circ} \mathrm{C}$ :

$$
\begin{aligned}
\text { Area } & =(500,000 \mathrm{mg} \mathrm{U} / \text { day }) /\left(4.6^{*} 10^{9 *} \operatorname{Exp}[-17,800 /(1.987 * \mathrm{~T})]^{* 24}\right) \\
& =2.5^{*} 10^{8} \mathrm{~cm}^{2}
\end{aligned}
$$

For the deoxygenated case:

$$
\begin{aligned}
\text { Area } & =(500,000 \mathrm{mg} \mathrm{U} / \text { day }) /\left(3.2^{*} 10^{8 *} \operatorname{Exp}\left[-13,800 /\left(1.98717^{*} \mathrm{~T}\right)\right]^{* 24}\right) \\
& =2.9^{*} 10^{6} \mathrm{~cm}^{2}
\end{aligned}
$$

If all of the damaged assemblies in K-East were declad, the geometric area would be $6^{*} 10^{7} \mathrm{~cm}^{2}$, so it first appears that the area calculated using oxygenated rates was unreasonably high. The assumption was then made that the uranium was corroding under deoxygenated conditions, even though the pool water was in direct contact with the atmosphere.

Since this initial evaluation, several new facts have come to light:

- The current steady state uranium corrosion rate in K-East appears to be 200 grams per day instead of 500 grams per day, as previously estimated.

- The fuel appears to be approximately 10 times as reactive as the unirradiated, uncorroded fuel used to generate the above rate constant correlations. This factor of 10 is based on the following lines of reasoning:

Literature Sources - Long-term aqueous corrosion was reported to increase the true surface area to geometric surface area ratio by a factor of 4 to 5 (Johnson and Pitner 1996). Secondly, the roughness factor did not consider the possibility of microcracking or radiation induced swelling. If one assigns a factor of 5 to microcracking and swelling and a factor of 5 to surface roughness, the sum of the increase in surface area over the geometric surface area is a factor of 10 . 
Experimental Modeling - Heat transfer modeling shows that increasing the effective/geometric surface area ratio by a factor of 6 , in one case, and 8 in another, were needed to successfully model furnace heating curves for spent fuel samples. Further TGA weight gain curves similarly showed wt gain rates varying from 6 to 10 times those expected from the measured geometric areas and the literature rate constants. These factors are conservatively rounded to a factor of 10 .

- The reaction rate in oxygenated liquid water is approximately $1 / 20$ the rate in deoxygenated liquid water, as cited earlier from Zima.

Using Equation 1, the recalculated surface area for oxygenated liquid water becomes:

$$
\begin{aligned}
\text { Area } & =200,000 \mathrm{mg} \mathrm{U} / \mathrm{d}^{*}\left((10 / 20)^{*} 24 \mathrm{hr} / \mathrm{d}^{*}(238 / 32)^{*} 10^{(7.634-3016 / \mathrm{T})}\right) \\
& =2.1 * 10^{6} \mathrm{~cm}^{2} \text { at } 10^{\circ} \mathrm{C}
\end{aligned}
$$

For deoxygenated liquid water:

$$
\begin{aligned}
\text { Area } & =200,000 \mathrm{mg} \mathrm{U} / \mathrm{d}^{*}\left(10^{*} 24^{*}(238 / 32)^{*} 10^{(7.634-3016 / \mathrm{T})}\right) \\
& =0.1 * 10^{6} \mathrm{~cm}^{2}
\end{aligned}
$$

This shows that the deoxygenated rate is too fast, and the calculations give a surface area less than the geometric area based on visual inspection. The oxygenated rate now yields a total surface area roughly four times the estimated geometric area.

The camera survey predicts $5 \mathrm{E}+05 \mathrm{~cm}^{2}$ reactive area for the intact fuel, and $2.1 \mathrm{E}+06 \mathrm{~cm}^{2}$ were predicted for the entire K-East basin. Possible reasons for this difference are:

- Inaccuracies in determining the pool corrosion rate

- Camera survey inaccuracies

- Non-visible area, such as microcracks in the fuel assemblies

- Scrap Fuel Area 
WHC-SD-SNF-TI-026

Revision 1

This page is intentionally left blank. 


\subsection{ASSIGNMENT OF REACTIVE URANIUM AREA TO MULTI-CANISTER OVERPACKS}

Many MCOs will contain little reactive uranium surface area, since the majority of fuel assemblies are unbreached, and the majority of those that are breached are not extensively corroded. About $80 \%$ of the failed outer elements and $97 \%$ of inner elements are judged to have minimal exposed corroding areas, based on visual inspections (Johnson and Pitner 1996; also see Table 1). There is no major concern for MCOs fitting the above description, since they will generate little chemical heat and hydrogen during the processing steps.

Because the surface area and system temperature are the dominant independent variables controlling the production of heat and gas generation, it is important to understand the maximum reactive uranium surface area that will be treated in a given $\mathrm{MCO}$.

The intent of this section is to describe the maximum surface area that could reasonably be placed in an MCO. The major concern is for those few MCOs that could potentially contain a large reactive surface area. Each MCO will contain at least 4 tiers, with 52 intact fuel assemblies in each tier. The remaining fifth tier may also consist of intact fuel assemblies or may include a basket filled with fuel rubble.

\subsection{WORST CASE ASSUMPTION OF THE CORRODING AREA OF FUEL ASSEMBLIES}

The worst case is an MCO that contains assemblies with split cladding in every rack position for the first 4 tiers and a scrap basket. The reactive surface area is calculated as follows:

$$
\begin{aligned}
& 208 \text { outer elements * } 17 \mathrm{~A}_{\text {ou }} * 14 \mathrm{Cm}^{2} / \mathrm{A}_{\text {ou }}=50,000 \mathrm{~cm}^{2} \\
& 165^{1} \text { inner elements * } 14 \mathrm{~A}_{\mathrm{iu}} * 7.1 \mathrm{~cm}^{2} / \mathrm{A}_{\text {iu }}=16,000 \mathrm{~cm}^{2}
\end{aligned}
$$

The total area is $66,000 \mathrm{~cm}^{2}$, representing $13 \%$ of the total estimated geometric area of the K-East fuel inventory.

While this stands as a worst case area for the K-East fuel inventory, the visibly degraded condition of fuel in the split cladding category offers the personnel loading the fuel into the MCOs, the basis to avoid loading an MCO predominantly with split cladding elements. The degree of mitigation of the worst case area indicated for an MCO loaded with split cladding fuel depends on the measures that the personnel are prepared to take to avoid compounding the surface area with a large inventory of split cladding elements in a single MCO.

This is the total number of identified inner elements with split cladding in the K-East fuel inventory. 


\subsection{INVENTORIES OF N-REACTOR FUEL SCRAP (RUBBLE)}

A major uncertainty in estimating the reactive uranium metal surface area is associated with the area of fuel segments in the scrap baskets. In this section, the known and projected inventories of scrap will be summarized for the K-East and $\mathrm{K}$-West fuel inventories.

\subsubsection{Current and Projected Fuel Scrap Inventories in the K-East Basin}

The previous and anticipated sources of fuel scrap are summarized in Table 2.

Observations from the Segregation Campaign were provided by V. L. Hoeffer and J. D. Mathews (see Johnson and Pitner 1996). Details of the visual assessment are also provided in Johnson and Pitner (1996). Karen Morris provided the inventory of fuel segments in the two canisters from the Loadout Pit campaign, based on N-Reactor fuel inventory records. However, note that only two canisters are involved, and one has already been included in Pitner's inventory.

The debris canisters are considered to contain non-fuel materials, predominantly Zircaloy "buggy spring" fuel assembly spacers. However, it is not clear whether some fuel segments also might have been placed in the debris canisters.

The upcoming MCO fuel loading campaign is assumed to generate a fuel scrap inventory similar to the Segregation Campaign inventory. In the Segregation Campaign, about $50 \%$ of the assemblies were disassembled, generating non-fuel debris and likely generating some fuel segments. Disassembly will not occur in the MCO Fuel Loading Campaign, so some rough handling of the fuel will be eliminated. On the other hand, the fuel will have corroded for more than an additional decade, so the fuel may be more susceptible to breakage in the upcoming campaign. The two effects are assumed to be offsetting in this assessment.

\subsubsection{Current and Anticipated Fuel Scrap Inventories in K-West}

In Table 3, the known and anticipated inventories of fuel scrap are indicated. Twelve scrap cans were loaded with fuel segments up to about 3 inches. The basis for the area estimate is a log normal distribution of fuel segment sizes from 0.5 to 3 inches. 
Table 2. Fuel Scrap (Rubble) Inventory in K-East Basin.

\begin{tabular}{|c|c|c|c|c|c|}
\hline Serap Source & Dates & $\begin{array}{c}\text { Scrap } \\
\text { Description }\end{array}$ & $\begin{array}{r}\text { Scrap } \\
\text { Inventory }\end{array}$ & $\begin{array}{c}\text { Basis for Area } \\
\text { Estimate }\end{array}$ & $\begin{array}{c}\text { Estimated } \\
\text { Surface Area, } \\
\mathrm{cm}^{2}\end{array}$ \\
\hline $\begin{array}{l}\text { Segregation } \\
\text { Campaign }\end{array}$ & $1983 / 84$ & $\begin{array}{l}\text { Fuel segments } \\
<6 \text { inches; few } \\
\text { segments } \\
<3 \text { inches } \\
\text { observed }\end{array}$ & $\begin{array}{l}\text { Approximately } \\
10 \text { canisters } \\
\text { (needs } \\
\text { confirmation) }\end{array}$ & $\begin{array}{l}3 \text {-inch sections, } \\
\text { stacked in } \\
52 \text { columns }\end{array}$ & $\begin{array}{l}12,000, \text { outers; } \\
7,000 \text { inners; } \\
20,000 \text { total in } \\
\text { worst case } \\
\text { canister }\end{array}$ \\
\hline $\begin{array}{l}\text { Visual } \\
\text { Inventory }\end{array}$ & 1996 & $\begin{array}{l}\text { Loose end caps; } \\
\text { element sections }\end{array}$ & $\begin{array}{l}\text { See Johnson } \\
\text { and Pitner } \\
(1996)\end{array}$ & $\begin{array}{l}\text { See Johnson and } \\
\text { Pitner (1996) }\end{array}$ & $\begin{array}{l}5 \times 10^{4} \text {, total in } \\
\text { K-East }\end{array}$ \\
\hline $\begin{array}{l}\text { Loadout Pit } \\
\text { Cleanup }\end{array}$ & 1992 & $\begin{array}{l}\text { a. } 4-6 \text { inch } \\
\text { sections (can } \\
\text { no. } 3911 \text { ) } \\
\text { b. } 9-26 \text { inch } \\
\text { sections (can } \\
\text { no. } 3910 \text { )* }\end{array}$ & $\begin{array}{l}\text { a. } 12 \mathrm{lb} . \mathrm{U} \text {; } \\
27 \mathrm{PCS} \text {. } \\
\text { b. } 208 \mathrm{lb} \mathrm{U} \text {; } \\
30 \mathrm{PCS} .\end{array}$ & $\begin{array}{l}\text { Not assessed; } \\
\text { one can already } \\
\text { assessed by } \\
\text { Pitner }\end{array}$ & Negligible \\
\hline $\begin{array}{l}\text { Loadout Pit } \\
\text { Cleanup }\end{array}$ & 1992 & $\begin{array}{l}\text { Principally non- } \\
\text { fuel debris** }\end{array}$ & 26 canisters & $\begin{array}{l}\text { Not assessed; } \\
\text { fuel inventory } \\
\text { unknown }\end{array}$ & Not assessed \\
\hline $\begin{array}{l}\text { MCO Fuel } \\
\text { Loading } \\
\text { Campaign }\end{array}$ & Future & $\begin{array}{l}\text { Assume similar } \\
\text { to Segregation } \\
\text { Campaign }\end{array}$ & $\begin{array}{l}10 \text { canisters, } \\
\text { estimated }\end{array}$ & $\begin{array}{l}\text { Assume same as } \\
\text { in Segregation } \\
\text { Campaign (see } \\
\text { above) }\end{array}$ & $\begin{array}{l}\text { Assume same as } \\
\text { in Segregation } \\
\text { Campaign (see } \\
\text { above) }\end{array}$ \\
\hline
\end{tabular}

* Two canisters; one already counted by Pitner.

** The debris canisters contain principally Zircaloy fuel element spacers; some fuel segments possible.

Two geometries were assumed: slices and pieces. The assumed geometries were converted to spheres with mean sizes indicated by the log normal assessment. The diameters of the two spheres are:

- slice geometry: $7.1 \mathrm{~cm}$

- piece geometry: $3.4 \mathrm{~cm}$

Based on these diameters, the metal volumes were calculated and converted to uranium metal weights. Dividing the weight per metal segment into $81 \mathrm{~kg}(180 \mathrm{lb}$.) (maximum allowable 
Table 3. Fuel Scrap (Rubble) Inventory in K-West Basin.

\begin{tabular}{|c|c|c|c|c|c|}
\hline Scrap Source & Dates & $\begin{array}{c}\text { Serap } \\
\text { Description }\end{array}$ & $\begin{array}{c}\text { Scrap } \\
\text { Inventory }\end{array}$ & $\begin{array}{c}\text { Basis for Area } \\
\text { Estimate }\end{array}$ & $\begin{array}{c}\text { Estimated } \\
\text { Surface Area, } \\
\mathrm{cm}^{2}\end{array}$ \\
\hline $\begin{array}{l}\text { N-Reactor } \\
\text { Campaign }\end{array}$ & Early $1980 \mathrm{~s}$ & $\begin{array}{l}\text { Fuel segments } \\
<3 \text { inches; } \\
\text { minimal small } \\
\text { particles }\end{array}$ & $\begin{array}{l}12 \text { canisters; } \\
<180 \text { \#U per } \\
\text { canister * }\end{array}$ & $\begin{array}{l}\text { Log normal } \\
\text { distribution of } \\
\mathrm{U} \text { metal } \\
\text { inventory }\end{array}$ & $\begin{array}{l}3,800 \mathrm{~cm}^{2} \text { per } \\
\text { canister (slice } \\
\text { geometry) } \\
7,200 \mathrm{~cm}^{2} \text { per } \\
\text { canister (piece } \\
\text { geometry) }\end{array}$ \\
\hline $\begin{array}{l}\text { Assumed } \\
\text { inventory } \\
\text { paralleling the } \\
\text { K East visual } \\
\text { inventory }\end{array}$ & Not applicable & $\begin{array}{l}\text { See Jolnnson } \\
\text { and Pitner } \\
\text { (1996) }\end{array}$ & $\begin{array}{l}\text { See Johnson } \\
\text { and Pitner } \\
(1996)\end{array}$ & $\begin{array}{l}\text { See Johnson } \\
\text { and Pitner } \\
(1996)\end{array}$ & $1 \times 10^{4} \mathrm{~cm}^{2}$ \\
\hline $\begin{array}{l}\text { MCO Fuel } \\
\text { Loading } \\
\text { Campaign }\end{array}$ & Future & $\begin{array}{l}\text { Assume similar } \\
\text { to Segregation } \\
\text { Campaign }\end{array}$ & 10 canisters est. & $\begin{array}{l}\text { Assume same } \\
\text { as Segregation } \\
\text { Campaign (see } \\
\text { Table 2) }\end{array}$ & $\begin{array}{l}\text { Assume same } \\
\text { as Segregation } \\
\text { Campaign (see } \\
\text { Table 2) }\end{array}$ \\
\hline
\end{tabular}

* Canister loading involved sweeping fuel segments too small to be handled with manipulators $(<3$ inches) into the scrap canisters from the sorting table; a large fraction of small particles ended up on the floor. The cans (with the possible exception of 1) were filled close to their 180 pound limit (Guzman 1996).

uranium weight per canister) indicated the number of equivalent spheres per canister: 23 for the slice geometry and 200 for the piece geometry. The areas of the respective spheres were calculated: $160 \mathrm{~cm}^{2}$ per segment for the slice geometry and $36 \mathrm{~cm}^{2}$ for the piece geometry.

The total areas in a canister for each of the geometries are indicated in Table 3 . The area added to an MCO can be assessed from these values and the number of these scrap canisters that are place in a given $\mathrm{MCO}$.

Assuming piece geometry for scrap and assuming split end fuel assemblies, one may calculate a total surface area of $80,000 \mathrm{~cm}^{2}$ for a worst case K-West MCO. Small particles that may have been swept into the scrap cans are likely to be largely oxidized if they were smaller than 0.06 in. $(0.15 \mathrm{~cm})$. There is additional concern that the handling and cleaning operations reduce the size of the present scrap during the upcoming load-out campaign. Since this fuel has been handled at least twice in the past without severe size degradation, it is believed that corrosion rather than handling is the process most likely to degrade component size. 
Corrosion is a surface area-driven phenomena, reducing the metal particle size at the surface. This corrosion process is typically quite slow in a pure water environment at ambient temperature. Although intergranular corrosion has been demonstrated for uranium fuel stored in water, the intergranular corrosion is typically only found at high magnification in the first millimeter of the surface.

During the upcoming fuel load-out campaign, it is planned to remove the fuel assemblies from the present fuel canisters, wash them, and load them in fuel baskets and load the baskets into the MCO. All residual pieces that do not pass through a 1/4-inch screen will be placed in scrap baskets that will also go into the MCO. This places an absolute lower size limit of $1 / 4$-inch on the scrap.

Given only the above information, the absolute theoretical worst case estimate for size distribution would be a scrap basket filled with 1/1/inch declad fuel pieces; since, by the testimony of the K Basins supervisors, small marble size pieces were not retained during the last fuel handling campaign. More practically, one realizes that there probably will not be enough $1 / 4$-inch scrap pieces in the K Basins canisters to fill a given scrap basket.

\subsubsection{Calculation of K-East Scrap Surface Area Based Upon One Inch Pieces}

It is much more likely that fuel assembly pieces ranging from 1 to 6 inches will form the bulk of the scrap. It is highly unlikely that a given scrap basket would be filled exclusively with 1-inch pieces; however, such a case can form the basis of a worst case scrap basket for safety evaluation.

If a scrap basket is filled with 1-inch pieces, it almost certainly would be filled with random order. This is difficult to treat mathematically, to determine the number of pieces and their corresponding surface areas. It was therefore decided, for the purposes of this model, to stack the pieces in vertical columns to approximate the shape of intact fuel assemblies. Fifty-two such columns can then be placed in the scrap basket. Each piece will contain four cross sectional area units $\left(2 \mathrm{~A}_{\mathrm{ou}}\right.$ and $\left.2 \mathrm{~A}_{\mathrm{iu}}\right)$.

This vertical stacking arrangement may seem too conservative when a random loading orientation of each piece seems more likely. However, the following ratios indicate that placing the number of 1 -inch pieces in 52 columns agrees surprisingly well with random placement.

- $($ Total scrap basket volume/volume of 52 assemblies $)=1.78$

- (Total scrap basket volume/volume of randomly placed stone riprap to fill the basket) $=1.77$ This ratio for stone riprap was calculated from stone riprap density data in Perry's engineering hand book. 
WHC-SD-SNF-TI-026

Revision 1

This allows a maximum area for scrap to be calculated as follows:

\section{Scrap outer assemblies:}

$$
26 \text { pieces/column * } 52 \text { columns * } 2 \mathrm{~A}_{\mathrm{ou}} / \text { piece } * 14 \mathrm{~cm}^{2} / \mathrm{A}_{\mathrm{ou}}=38,000 \mathrm{~cm}^{2}
$$

\section{Scrap inner assemblies:}

$$
26 \text { pieces/column } * 52 \text { columns } * 2 \mathrm{~A}_{\mathrm{iu}} / \text { piece } * 7.1 \mathrm{~cm}^{2} / \mathrm{A}_{\mathrm{iu}}=19,000 \mathrm{~cm}^{2}
$$

By adding these reactive surface areas, the reactive surface area for a worst case MCO is found to be $120,000 \mathrm{~cm}^{2}$.

\subsubsection{Calculation of K-East Scrap Surface Area Based upon Log Normal Distributions}

Scrap is created by three mechanisms:

- Surface corrosion

- Intergranular Corrosion

- Mechanical shock

\subsubsection{Surface Corrosion Scrap}

Scrap resulting from surface corrosion is typically micron sized pieces of metal that are agglomerated in the oxide scale coating. These micron sized pieces react fairly quickly with the pool water upon oxide spalling and in any event are expected to be largely eliminated by the washing and screening process.

\subsubsection{Intergranular Corrosion Scrap}

Scrap particles created by intergranular corrosion are expected to range from several microns to several $\mathrm{mm}$. in diameter. A log normal distribution is expected from this type of scrap. Again, because of the small size of this scrap and the likelihood of its reaction in the pool water and its exclusion by the washing and screening process, it will not be further considered here as a significant source of scrap in the MCO.

\subsubsection{Mechanical Shock Scrap}

The irradiated uranium metal is much more brittle than the original material and is susceptible to cracking from mechanical shock. Once cracked, the metal pieces are pried apart 
by the penetration of hydrogen, and the precipitation of $\mathrm{UH}_{3}$ within the crack. Very little is actually known about the resulting particle size distribution. If we assume a log normal distribution, we may postulate a reasonable distribution as presented in Figure 1.

Figure 1. Assumed Particle Size Distribution for Mechanical Shock Scrap.

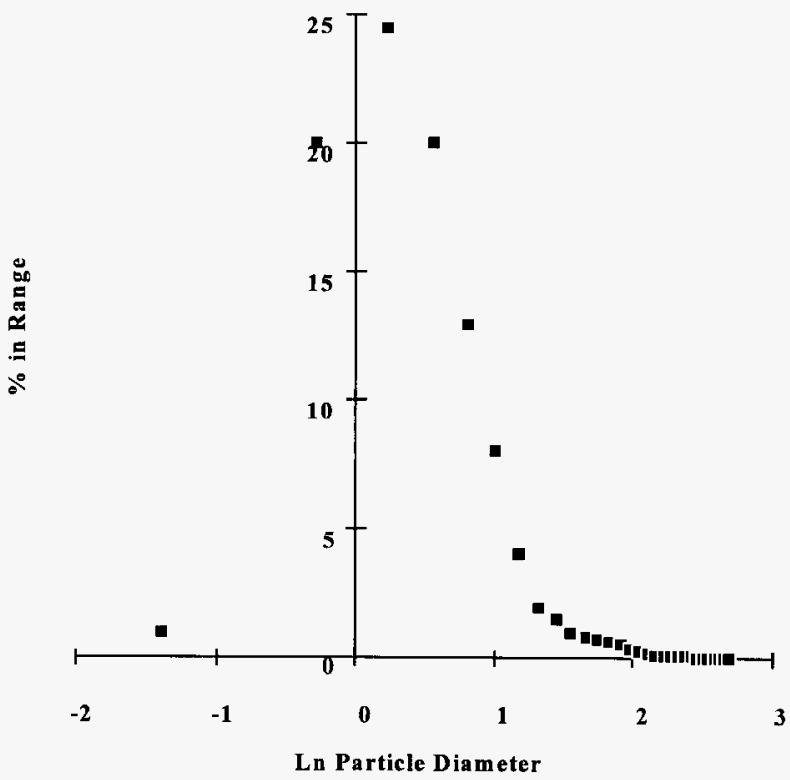


With a particle size range from $0.1 \mathrm{~cm}$ to $15 \mathrm{~cm}$, a geometric mean of $1.25 \mathrm{~cm}$. and a geometric standard deviation of $1.50 \mathrm{~cm}$ was estimated.

It would be very laborious to attempt to calculate the surface area of the particles based upon the surface area distribution given in Figure 1. It is much easier to mathematically create another distribution with the same number of particles and the same total area, but with a single particle diameter. This single particle diameter is given by:

$$
\ln \mathrm{X}_{\mathrm{ns}}=\ln \mathrm{X}_{\mathrm{gm}}+1.0 \mathrm{Ln}^{2} \sigma_{\mathrm{g}^{2}}
$$

where:

$$
\begin{aligned}
& \begin{aligned}
\mathrm{X}_{\mathrm{rls}} & =\text { the diameter of the uni-sized spheres } \\
& =2.8 \mathrm{~cm} . \\
\mathrm{X}_{\mathrm{gm}} & =\text { the geometric mean diameter } \\
& =1.25 \mathrm{~cm}
\end{aligned} \\
& \begin{aligned}
\sigma_{\mathrm{g}} & =\text { the geometric standard deviation } \\
& =1.5 \mathrm{~cm}
\end{aligned}
\end{aligned}
$$

The mass of these uni-dimensional spheres is $222 \mathrm{gms}$, and the area $=25$ square $\mathrm{cm}$.

Now the area within a scrap basket can be calculated. We know that we can expect approximately 20 canisters of scrap in each of the basins. Each canister contains approximately $81 \mathrm{~kg}$ of uranium metal scrap. One can therefore calculate that each canister contains:

$(81000 \mathrm{~g} / 222 \mathrm{~g} / \mathrm{uni}-$ sphere $) * 25 \mathrm{~cm} 2=9000 \mathrm{~cm}^{2}$

and if 6 canisters of scrap are placed in each scrap basket, the scrap surface area will be 54,000 square $\mathrm{cm}$. This result is almost the same as the result obtained by stacking 1 inch slices. Since the log normal distribution is more likely and reasonable, it will be used as the scrap estimate in the MCO. 


\subsection{CONCLUSIONS}

\subsection{CORRODING AREA IN K-EAST POOL}

Based on current information regarding the $\mathrm{N}$ Reactor fuel inventory, the geometric and true surface areas can only be roughly estimated.

\section{Radiometric Estimate}

- based on the ${ }^{137} \mathrm{Cs}$ release rate, the Pearce rate equations, and an adjustment for the corrosion rate for oxygenated water cited by Zima (1960), the geometric area of the corroding $\mathrm{K}$ East fuel was estimated to be $2.1 \times 10^{6} \mathrm{~cm}^{2}$. his surface area will be reduced by whatever fraction of the total corrosion that is occurring anoxically.

\section{Visual and Mathematical Estimates}

- The geometric area of corroding fuel assemblies in the K East inventory was estimated to be $5 \times 10^{5} \mathrm{~cm} 2$. The error in this geometric area is estimated to not exceed $25 \%$.

- The geometric area of scrap in the current 10 canisters was mathematically estimated to be $9 \times 10^{4} \mathrm{~cm}^{2}$.

The total of the two sources is $5.9 \times 10^{5} \mathrm{~cm}^{2}$. This is approximately 4 times less than the radiometric estimate.

Potential sources for the above discrepancy are:

1. The radiometric estimate contains assumptions:

- We assume that the distribution of ${ }^{137} \mathrm{Cs}$ within a given fuel assembly is flat radially and axially, and that the ratio of ${ }^{137} \mathrm{Cs} / \mathrm{U}$ remains unchanged as the fuel assembly corrodes.

- We assume that the ${ }^{137} \mathrm{Cs}$ does not absorb abnormally on the oxide surfaces within the pool.

- We assume that once the uranium corrosion rate is established, radiometrically, the proper reaction rate can be established. We assumed oxygenated liquid water kinetics. If only $10 \%$ of the corrosion is occurring within cracks or deep sludge beds where oxygen is diffusion limited, the radiometric estimate would match the visual estimates. 
2. The visual estimate is not precise. It is estimated that different persons interpreting the camera survey information would vary in their results by $25 \%$.

3. The mathematical analysis of the scrap surface area is not precise. The surface area distribution was presented as a reasonable estimate but is not experimentally determined.

Considering all of the above sources of potential error, the most significant is the type of kinetics chosen for the corrosion reaction in the radiometric estimate and it is recommended that the visual and mathematical results be accepted for further analytical work.

\subsection{CORRODING AREA ESTIMATES FOR AN MCO}

\subsubsection{Case MCO}

A major conclusion from the visual approach is that the split cladding category provides the dominant corroding area. Depending on assumptions regarding the fuel inventory that is loaded into a given $\mathrm{MCO}$, a geometric area of $66,000 \mathrm{~cm}^{2}$ can be predicted if the inventory is predominantly split cladding.

The area would be further augmented by loading scrap baskets into the same MCO, as illustrated below. Because the split cladding elements are readily recognized, there is a basis for operators to preclude loading a single MCO with a large inventory of split cladding fuel.

Estimating the area of fuel scrap is a major challenge. A mathematical model assuming a $\log$ normal distribution permits an estimate of $54,000 \mathrm{~cm}^{2}$ for the fuel scrap in an MCO. A worst case MCO containing 4 tiers of split cladding fuel and a scrap basket would therefore contain:

- $66,000 \mathrm{~cm}^{2}$ for split cladding

- $54,000 \mathrm{~cm}^{2}$ for scrap

The total corroding geometric area in the MCO would be about $120,000 \mathrm{~cm}^{2}$.

This area can be administratively controlled by assuring that the inventory of split cladding is minimized in any given MCO and by reducing the amount of scrap in a given scrap basket. 


\subsubsection{Average Surface Area in an MCO}

The average geometric surface area in the average MCO containing K-East fuel, can be obtained by dividing the total surface area $5.9 \times 10^{5} \mathrm{~cm}^{2}$ by the $200 \mathrm{MCOs}$ planned for this transfer. This average reactive surface area is slightly less than $3,000 \mathrm{~cm}^{2}$.

If there is a need to improve the corroding surface area perspective, the following should be considered (see also Johnson and Pitner 1996):

- additional definition of the characteristics of the corroding inventories, particularly the lower ends of the K East elements and the inventory in K West

- a more factual basis to define a model for sizing the scrap basket inventories

- a more factual basis to predict fuel scrap generation in the MCO loading campaign, including systematic observations of fuel friability as the fuel is handled

- experiments to measure rate constants for the corrosion of $\mathrm{N}$ Reactor fuel in $\mathrm{K}$ East and $\mathrm{K}$ West conditions

- results from the Characterization Program that define the factors that contribute to true surface area or experiments that evaluate the reactivity of a given geometric area.

\subsubsection{True Surface Areas}

The above estimates are geometric surface area estimates. It is recognized that surface roughness, irradiation induced fuel swelling, intergranular corrosion, and cracking are all factors that increase the area above that measured geometrically. At the present it is suggested that these effects for $\mathrm{N}$-fuel can be bounded by applying a factor of 10 to the geometric surface area. 


\subsection{REFERENCES}

WHC, 1995, K Basin Corrosion Program Report, WHC-EP-0877, Westinghouse Hanford Company, Richland, Washington.

WHC, 1995, K East Basin Underwater Visual Fuel Survey (1995), WHC-SD-SNF-TI-012, Westinghouse Hanford Company, Richland, Washington.

WHC, 1996, SNFP Recommended Reaction Rate Constants for Corrosion of N-Reactor Fuel, WHC-SD-SNF-TI-020, Westinghouse Hanford Company, Richland, Washington.

WHC, 1996, Spent Nuclear Fuel Project Recommended Reaction Rate Constants for Corrosion of N-Reactor Fuel, WHC-SD-SNF-TI-020, Westinghouse Hanford Company, Richland, Washington.

Guzman, M., 1996, Personal Communication, Westinghouse Hanford Company, Richland, Washington.

Johnson, A. B. Jr. and A. L. Pitner, 1996, Surface Area Considerations for Corroding N Reactor Fuel, PNNL-1 1174, Pacific Northwest National Laboratory, Richland, Washington.

Ritchie, A. G., 1981, Journal of Nuclear Materials, 102 (1981) 170.

Tyfield, S. R., 1988, Nuclear Energy, April 27, No.2, 91-98.

Zima, G. E., 1960, Pyrophoricity of Uranium in Reactor Environments, HW-62442, January 22, Hanford Atomic Products Operation, General Electric Company, Richland, Washington. 
WHC-SD-SNF-TI-026

Revision 1

This page intentionally left blank. 


\begin{tabular}{|c|c|c|c|c|c|}
\hline \multicolumn{6}{|c|}{ DISTRIBUTION SHEET } \\
\hline To & \multirow{2}{*}{\multicolumn{3}{|c|}{$\begin{array}{l}\text { From } \\
\text { Plutonium Process Support } \\
\text { Laboratory/Thurman Cooper }\end{array}$}} & \multicolumn{2}{|l|}{ Page 1 of 1} \\
\hline Distribution & & & & \multicolumn{2}{|l|}{ Date 09/23/96 } \\
\hline \multirow{2}{*}{\multicolumn{4}{|c|}{$\begin{array}{l}\text { Project Title/Work Order } \\
\text { SNFP Surface Area Estimates for N-Reactor Fuel in the } K \text { East Basin. WHC-SO- } \\
\text { SNF-TI-026, Rev. } 1\end{array}$}} & \multirow{2}{*}{\multicolumn{2}{|c|}{$\begin{array}{l}\text { EDT No. } \\
\text { ECN No. } 636403616630 \\
6303\end{array}$}} \\
\hline & & & & & \\
\hline Name & MSIN & $\begin{array}{c}\text { Text } \\
\text { with } \\
\text { All } \\
\text { Attach. }\end{array}$ & Text Only & $\begin{array}{l}\text { Attach./ } \\
\text { Appendix } \\
\text { Only }\end{array}$ & $\begin{array}{c}\text { EDT/ECN } \\
\text { Only }\end{array}$ \\
\hline $\begin{array}{l}\text { J Abrefah } \\
\text { GS Barney } \\
\text { GD Bazinet } \\
\text { LD BTackburn } \\
\text { TO Cooper } \\
\text { RG Cowan } \\
\text { ER Cramer } \\
\text { DR Duncan } \\
\text { FD Fisher } \\
\text { JR Frederickson } \\
\text { FJ Heard } \\
\text { JJ Irwin } \\
\text { A Johnson } \\
\text { AT Kee } \\
\text { CR Miska } \\
\text { SD Nunn } \\
\text { DM Ogden } \\
\text { PA Scott } \\
\text { PK Shen } \\
\text { DA Sirith } \\
\text { TA Thornton } \\
\text { JC Wiborg } \\
\text { AM Zaman } \\
\text { Central Files (orig + 1) } \\
\text { SNF Project files }\end{array}$ & 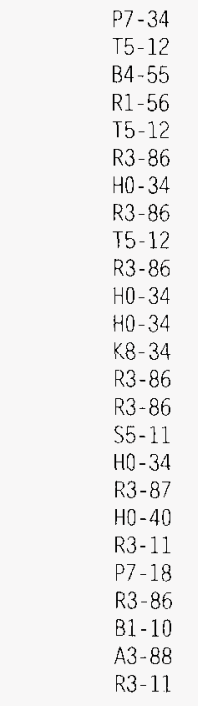 & $\begin{array}{l}x \\
x \\
x \\
x \\
x \\
x \\
x \\
x \\
x \\
x \\
x \\
x \\
x \\
x \\
x \\
x \\
x \\
x \\
x \\
x \\
x \\
x \\
x \\
x \\
x\end{array}$ & & & \\
\hline
\end{tabular}

